$100.30^{-95} 85(2)$

Report No.

WR-B-95-06
U.S. Department of Fnergy

Office of Inspector General
Release Date:

May 5, 1995

\title{
Report on \\ Audit of Construction of \\ Protective Force Training \\ Facilities at the Pantex \\ Plant
}

DISTRIBUTION OF THIS DOCUMENT IS UNLIMITED

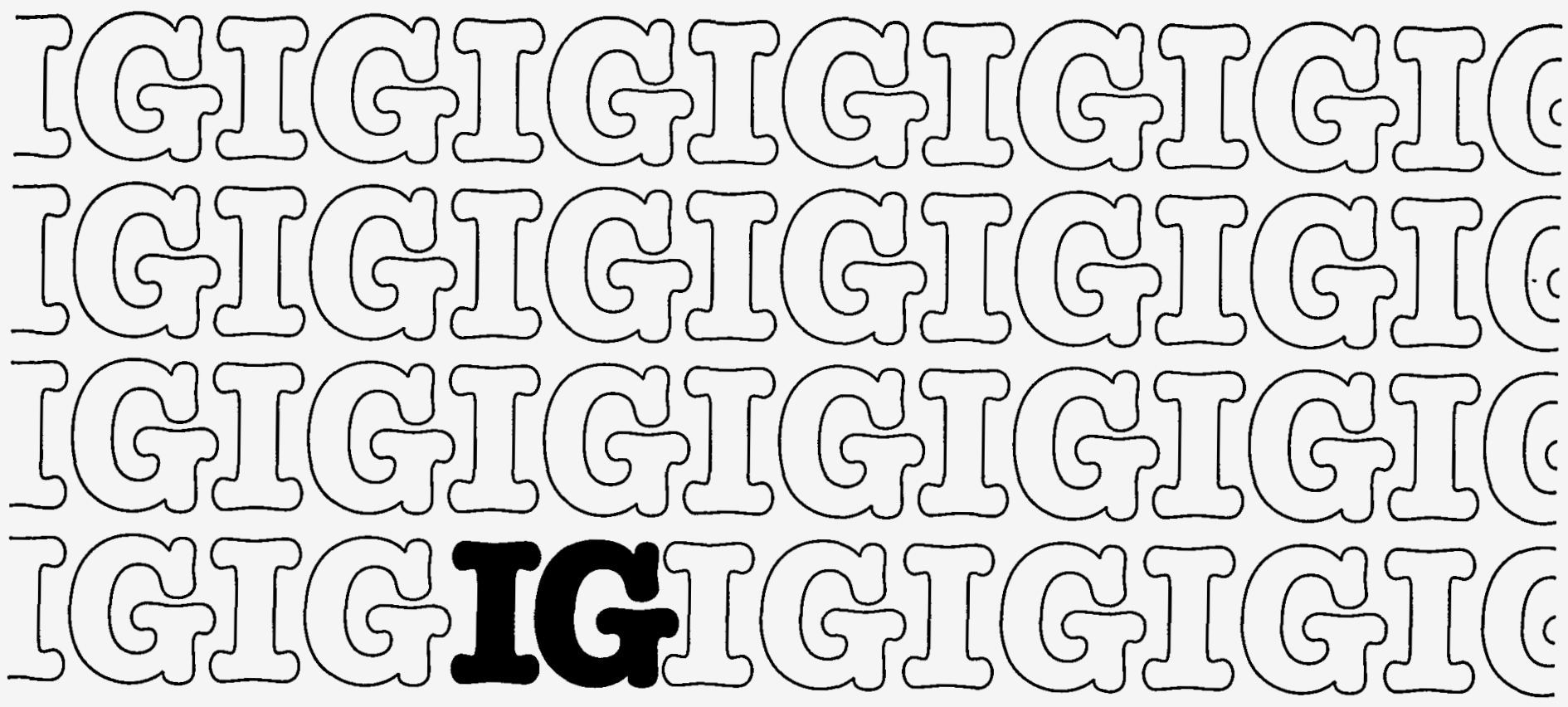


This report can be obtained from the

U.S. Department of Energy

Office of Scientific and Technical Information

P.O. Box 62

Oak Ridge, Tennessee 37831 
U.S. DEPARTMENT OF ENERGY

OFFICE OF INSPECTOR GENERAI

AUDIT OF CONSTRUCTION OF PROTECTIVE FORCE

TRAINING FACILITIES AT THE PANTEX PLANT

Report Number: WR-B-95-06.

Date of Issue: May 5, 1995
Western Regional Audit Office

Albuquerque, NM 87185-5400 


\section{DISCLAIMER}

This report was prepared as an account of work sponsored by an agency of the United States Government. Neither the United States Government nor any agency thereof, nor any of their employees, make any warranty, express or implied, or assumes any legal liability or responsibility for the accuracy, completeness, or usefulness of any information, apparatus, product, or process disclosed, or represents that its use would not infringe privately owned rights. Reference herein to any specific commercial product, process, or service by trade name, trademark, manufacturer, or otherwise does not necessarily constitute or imply its endorsement, recommendation, or favoring by the United States Government or any agency thereof. The views and opinions of authors expressed herein do not necessarily state or reflect those of the United States Government or any agency thereof. 


\section{DISCLAIMER}

Portions of this document may be illegible in electronic image products. Images are produced from the best available original document. 
AUDIT OF CONSTRUCTION OF PROTECTIVE FORCE TRAINING FACILITIES AT THE PANTEX PLANT

TABLE OF CONTENTS

Page

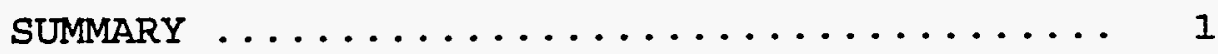

PART I - APPROACH AND OVERVIEW $\ldots \ldots \ldots \ldots \ldots \ldots \ldots \ldots$

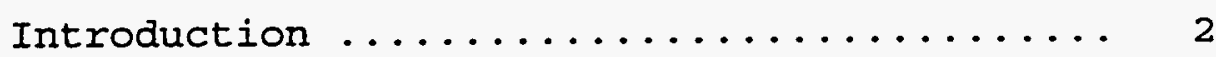

Scope and Methodology ............... 2

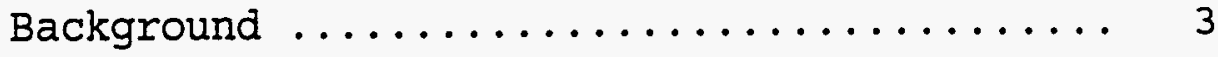

Observations and Conclusions .......... 3

PART II - FINDINGS AND RECOMMENDATIONS .......... 5

1. Physical Training Facility .......... 5

2. Weapons Tactics and Training Facility .. 12

PART III - MANAGEMENT AND AUDITOR COMMENTS ......... 15 
U.S. DEPARTMENT OF ENERGY

OFFICE OF INSPECTOR GENERAL

OFFICE OF AUDIT SERVICES

\section{AUDIT OF CONSTRUCTION OF PROTECTIVE FORCE TRAINING FACILITIES AT THE PANTEX PLANT}

Audit Report Number: WR-B-95-06

\section{SUMMARY}

A goal of the Department of Energy project management system is to ensure that projects are necessary to fulfill mission needs and are cost effective. This requires that the Department justify each project and explore competitive alternatives. The objective of this audit was to assess the need to construct protective force training facilities at the Department's Pantex Plant.

Our audit disclosed that (1) construction of a physical training facility was not necessary to fulfill mission needs, and (2) the Department did not consider all viable alternatives to constructing a weapons tactics and training facility. These conditions occurred, in part, because a Justification for New Start was never prepared and approved for the Security Enhancements Major System Acquisition, which included these two projects.

We recommended that the Manager, Albuquerque Operations office, cancel construction of the physical training facility, make needed repairs and upgrades to the existing facilities, and reduce the cost of the Security Enhancements Major System Acquisition accordingly. Implementation of this recommendation will save about $\$ 1.7$ million. We also recommended that the Manager direct Mason \& Hanger to perform economic analyses of all viable alternatives to constructing a weapons tactics and training facility before proceeding with construction. Such analyses could lead to cancellation or rescoping of the proposed facility and result in savings to the Department.

Albuquerque management did not agree to cancel construction of the physical training facility, but did agree to perform economic analyses of all viable alternatives to the proposed weapons tactics and training facility before proceeding with construction.

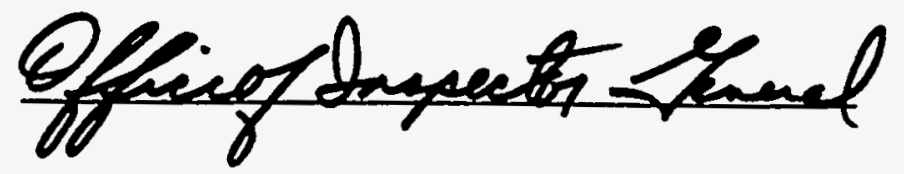




\title{
PART I
}

\author{
APPROACH AND OVERVIEW
}

\section{INTRODUCTION}

Ensuring that the construction of new facilities is needed to meet mission requirements is extremely important in a time of declining funds and budget deficits. Accordingly, we undertook this audit to assess the need to construct protective force training facilities at the Department of Energy's (Department) Pantex Plant. More specifically, the audit objectives were to determine whether construction of a physical training facility was necessary to meet mission requixements; and whether economic analyses were performed of all viable alternatives to constructing a proposed weapons tactics and training facility.

\section{SCOPE AND METHODOLOGY}

The audit was conducted at the Department's Headquarters, Pantex Plant (Pantex), and Albuquerque Operations office (Albuquerque). The audit was conducted between February and October 1994.

To accomplish the audit objectives, we:

- Reviewed Departmental orders;

- Interviewed Albuquerque and Pantex personnel;

- Reviewed construction project documents, such as conceptual design reports;

- Identified training requirements for the Pantex protective force; and;

- Toured existing physical and weapons training facilities.

The audit was made according to generally accepted Government auditing standards for performance audits, which included tests of internal controls and compliance with laws and regulations to the extent necessary to satisfy the objectives of the audit. 
We assessed significant internal controls with respect to the Department's project management system. our assessment identified key internal control procedures for justifying construction projects and tested the operation of those procedures. While we concluded that the controls as designed were sound, we found weaknesses in their implementation, as discussed in Part II of the report. We did not rely extensively on computer-processed data and, therefore, did not fully examine the reliability of the data. Because our review was limited, it would not necessarily have disclosed all internal control deficiencies that may have existed.

An exit conference was held with Albuquerque and Pantex representatives on March 3, 1995. Subsequent meetings were held to resolve our differences without success.

\section{BACKGROUND}

The Department's Pantex Plánt, located 25 miles northeast of Amarillo, Texas, is managed and operated by Mason \& Hanger-Silas Mason Co., Inc. (Mason \& Hanger). A primary mission of Pantex is to disassemble nuclear weapons.

Protective forces at Pantex are to be managed, trained, and equipped to meet basic security and emergency response requirements. Training to fulfill mission requirements under a Department-approved program includes meeting a physical fitness qualification standard and exercising a minimum of 3 hours per work week. Protective force officers are also required to meet weapons qualifications for all assigned weapons.

To fulfill these mission requirements, the Department in 1985 proposed the construction of a physical training facility and a weapons tactics and training facility. These projects, with total project costs of $\$ 2.6$ million and $\$ 5.7$ million, respectively, were part of a twelve-project Security Enhancement Major System Acquisition that was initially funded in Fiscal Year 1988. The total project cost of the Major System Acquisition was $\$ 130$ million.

\section{OBSERVATIONS AND CONCLUSIONS}

Because Federal "major systems" are expensive (currently $\$ 100$ million or more), there has been continuing concern about the management of these acquisitions. To address this concern, the office of Management and Budget initiated in 1976 a formal acquisition process that is described in Circular A-109. In 1978, the Department 
promulgated principles, policies, and procedures to implement and institutionalize the Circular.

While the Department has simplified its procedures over time, two of the objectives of both the Circular and the Department's system have remained constant. Those objectives are to ensure that (1) major system acquisitions are necessary to fulfill a mission need, and (2) competitive alternatives are explored to prevent choosing more costly or less effective options. However, our audit showed that these objectives were not being achieved, because (1) construction of a physical training facility was not necessary to meet mission needs, and (2) the Department did not consider all viable alternatives to constructing a weapons tactics and training facility. Although existing physical training facilities are in need of some repairs and upgrades, and existing classroom space is limited, the pantex protective force has successfully met its training requirements.

Ensuring that new projects are necessary and cost effective is especially important in light of decreasing budgets and the Department's commitment to contribute to the administration's deficit reduction objectives. According to the administration's Fiscal Year 1995 budget for stockpile support, which includes facility construction for the Pantex plant, funding will drop from approximately $\$ 2.1$ billion in Fiscal Year 1994 to an estimated $\$ 1.6$ billion in Fiscal Year 1995.

Management should consider these conditions when preparing the yearend assurance memorandum on internal controls. 


\section{PART II}

\section{FINDINGS AND RECOMMENDATIONS}

\section{Physical Training Facility}

\section{FINDING}

A primary objective of the Department's Project Management System is to ensure that the Department only pursues projects that fulfill mission needs. However, we found that the Department planned to construct a $\$ 2.6$ million physical training facility for the Pantex protective force that was not necessary. Although some repairs and upgrades were needed to existing facilities, and existing classroom space was limited, training requirements were successfully being met. Several factors possibly contributed to continued pursuit of the project since 1985, including the absence of a critical examination of whether a mission need existed to justify a new facility. Cancelling the project would save about $\$ 1.7$ mililion.

\section{RECOMMENDATION} office:

We recommend that the Manager, Albuquerque Operations

- Cancel construction of the proposed physical training facility;

- Make needed repairs and upgrades to the existing facilities to bring them into compliance with National Fire Protection Act and Americans With Disabilities Act requirements; and,

- Reduce the total cost of the Security Enhancements Major System Acquisition accordingly.

\section{MANAGEMENT REACTION}

Management did not respond to the above recommendation, as stated. See Part III for additional information.

\section{DETAILS OF FINDING}

\section{EXISTING FACILITIES}

Physical training of the Pantex protective force is currently conducted in three portable buildings which, according to Department records, were manufactured and acquired in 1985. The buildings each measure about 63 feet 
by 23 feet, and provide adequate space for the exercise equipment they contain. Two additional security training facilities, with 3,200 and 600 square feet respectively, provide office space and classrooms. See Figures 1, 2, and 3 for photos of the existing facilities.

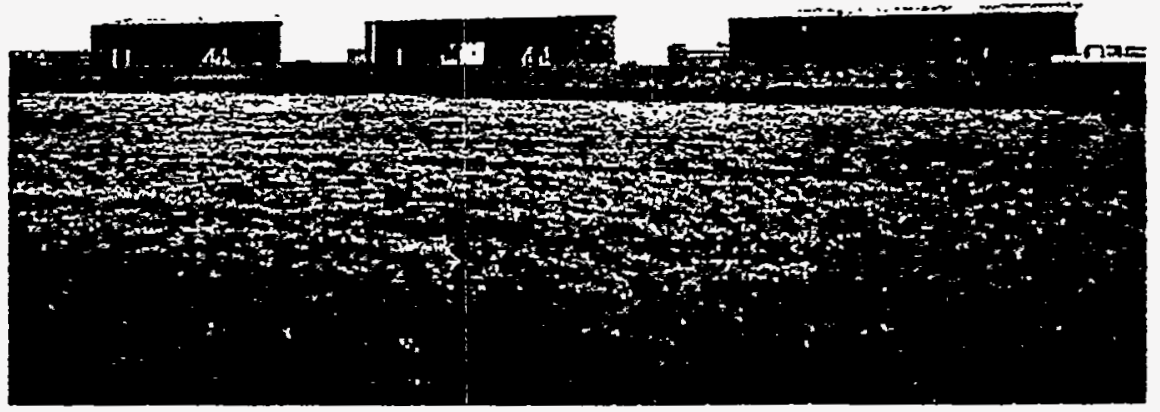

Figure 1. Exterior Photo of Physical Training Facilities 


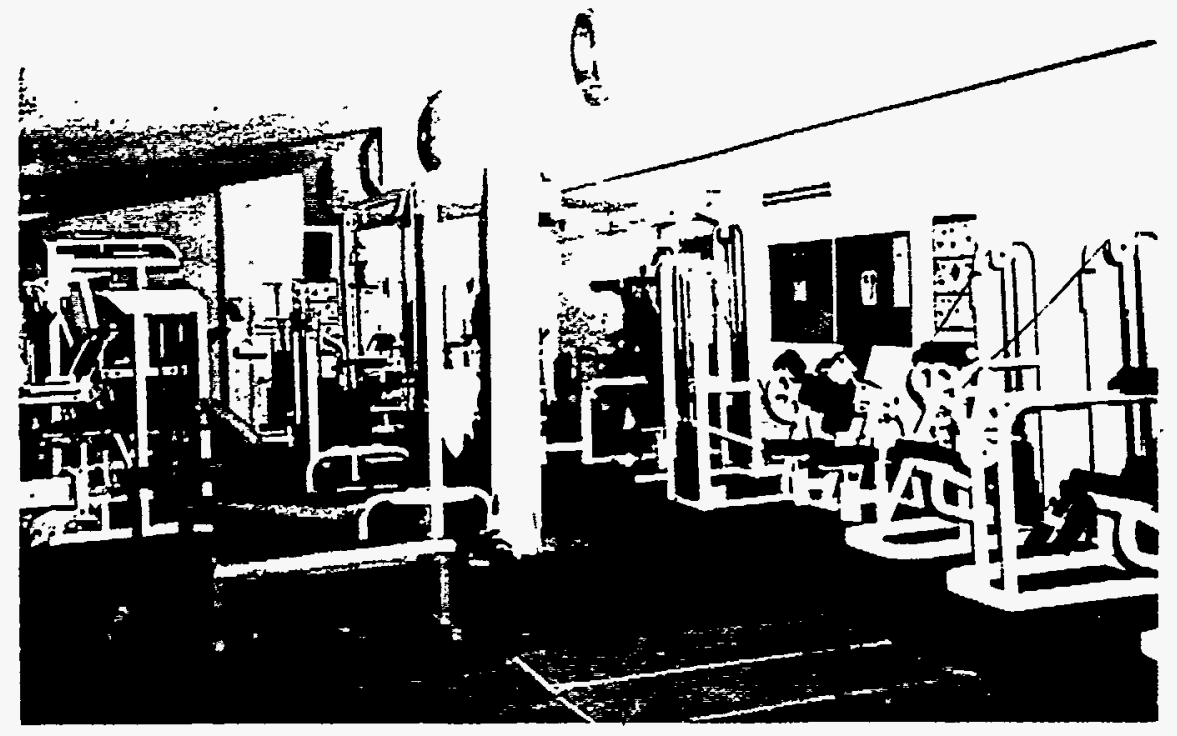

Figure 2. Interior Photo of Physical Training Facility

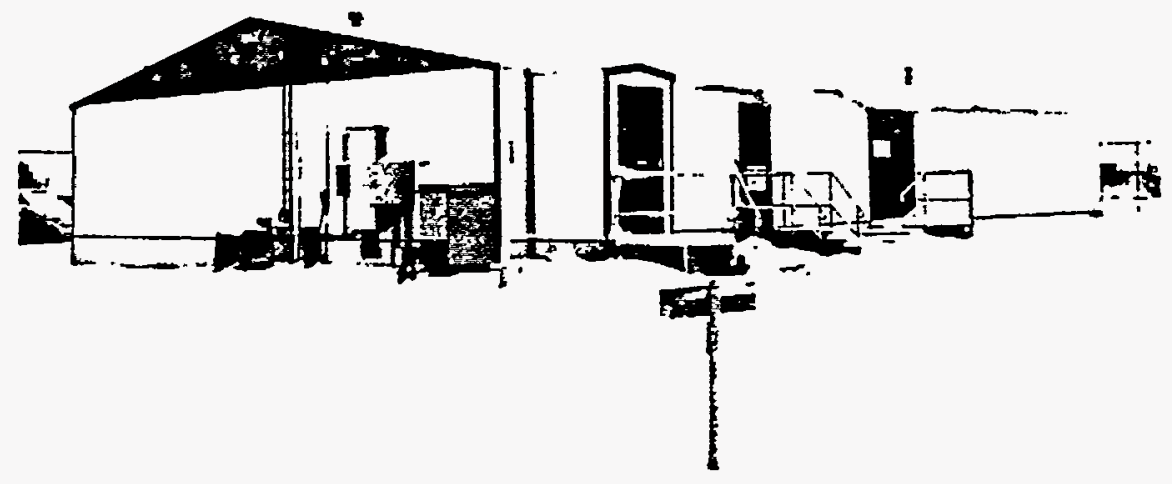

Figure 3. Exterior Photo of Security Training Facility 


\section{JUSTIFICATION AND DESCRIPTION OF PROPOSED FACILITY}

According to the Fiscal Year 1995 Congressional Budget Request, the proposed physical training facility is necessary to provide a centralized, permanent facility for the physical training of the Pantex protective force. The buildings currently in use were not designed for physical training. Consequently, the physical training program must be limited to that which can be housed in such structures.

The proposed 11,000 square foot physical training facility will provide offices, classrooms, and a large indoor exercise area for security personnel to accommodate on-site training and conditioning. The proposed facility will be in a limited area of the Pantex Plant and subdivided internally into three functional zones. The north zone of the building will contain 2 classrooms, office space for 11 persons, and facility support rooms. The south zone will contain the exercise room, training and testing offices for two persons, and rest rooms and showers. The central zone, which is a circulation corridor providing internal access to either of the other two zones, will contain trophy display areas.

\section{DEPARTMENT PROJECT MANAGEMENT SYSTEM}

A specific objective of the Department's Project Management System, established in Department Order 4700.1, is to ensure that projects are based on clearly defined missions and mission analyses. This goal is reached, in part, by requiring that each major system acquisition have an approved "Justification of Mission Need" (previously called a "Justification for New start"). This justification identifies mission needs, the purpose and priority of the project in supporting the needs, and the significance of meeting the needs.

\section{NEED FOR THE PROPOSED PHYSICAL TRAINING FACILITY}

We found that construction of a $\$ 2.6 \mathrm{million}$ physical training facility was not necessary to fulfill mission requirements. Although existing facilities were in need of repair, they were adequate for physical training as evidenced by the protective forces' physical fitness qualification rate. In addition, the proposed facility will not enhance the physical training program. 
Protective Force Qualification Rate

Mission requirements for Pantex security police officers include meeting a physical fitness qualification standard and exercising a minimum of 3 hours per work week. According to data provided by the senior training specialist, Pantex security police officers successfully met the physical fitness qualification standard in 2,330 of 2,336 attempts made from 1986 through 1993, for a 99.7 percent success rate. As of March 1994, the current year's qualification rate was 100 percent. In addition, security police officers were exercising a minimum of 3 hours per work week. Thus, the existing facilities have not affected the Pantex protective force's ability to meet its mission requirements.

There may be less need for physical training in the future, depending on the outcome of a Department evaluation. In audit report number DOE/OIG-354, "Report on Audit of the Management and Cost of the DOE's Protective Forces," July 1994, the Department agreed to conduct an evaluation of the physical training program. The evaluation will consider policy changes to reduce or eliminate the number of physical fitness exercise hours required per 7-day period. The report also stated that field security officials at Pantex, Sandia, and Los Alamos indicated that because security Police officers I and II have Iimited response requirements and their duties are not physically taxing, they should not be required to meet physical fitness standards. As of September 30,1994 , about 70 percent of the 370 security officers at Pantex were classified as security Police Officers I or II. Eliminating the physical fitness standard for these officers would substantially reduce the need for a physical training facility.

\section{Adequacy of Existing Facilities}

As part of a comprehensive safeguards and security inspection of the Pantex Plant performed in september and October of 1992, the Deputy Assistant Secretary for Security Evaluations examined the protective force training facilities at pantex. The physical fitness facilities were inspected to determine their adequacy in meeting Departmental needs. In its report, Security Evaluations concluded that management had provided adequate resources to support and guide the protective force training program. In addition, Pantex had the facilities and equipment necessary to carry out the protective force mission.

We also concluded that the existing facilities were adequate. Although we observed items that were in need of 
repair, there were no deficiencies in the existing

facilities that, in our opinion, warranted construction of a new facility. According to estimates prepared by Mason \& Hanger, the existing facilities could be repaired and brought into compliance with National Fire Protection Act and Americans with Disabilities Act requirements for about $\$ 500,000$, which was acceptable to the Pantex Division Manager for Safeguards, Security and Fire Protection. In addition, portable buildings were adequate for physical training. According to a portable building manufacturer, buildings similar to those in use at Pantex were used for physical training by several school systems and a computer chip manufacturer located in New Mexico.

Facility Enhancements to the Physical Training Program

The proposed physical training facility would not enhance the physical training program because no exercise equipment would be added. Rather, equipment located in the existing facilities would be relocated to the new facility. The new facility would contain about 3,355 square feet of exercise space, 1,945 square feet of office space, 2,200 square feet of classrooms. The remaining 3500 square feet would consist of rest rooms with shower facilities, storage and mechanical rooms, and corridors. The office space is for security training personnel, who presently have offices elsewhere. The classrooms are for security training, but such training could continue to be given at existing classrooms throughout the Pantex Plant. Completion of the proposed weapons tactics and training facility will include two classrooms. Offices and classrooms cannot significantly enhance an already high qualification rate.

\section{POSSIBLE CONTRIBUTING FACTORS}

Several factors possibly explain why the Department continued to pursue construction of the facility. First, the reasons shown in the project documents for constructing the facility did not address a mission need. For example, the project's Conceptual Design Report, issued in February 1988, stated that the facility was needed because the physical training program was limited to that which could be housed in the existing facilities. There was no mention of how this Iimitation affected the protective force's ability to meet the Department's physical training requirements.

Second, the project may not have been adequately scrutinized as addressing a mission need because it was relatively low cost and low priority. The proposed facility will not reduce risk. In fact, the project has been 
designated a low priority within the entire Major System Acquisition.

Finally, a Justification for New Start was never prepared and approved for the Security Enhancements Major System Acquisition, which included the Physical Training Facility project. This justification, requiring acquisition executive approval, would have addressed mission needs and documented managements' consideration of alternatives and support for the option selected.

The Department waived the requirement for an approved Justification for New Start on two separate occasions. The requirement was waived in 1987 when the Department ruled that an ongoing Safeguards and Security Major Project, established in 1985, was not required to develop typical Major Project documentation. Pantex Security Enhancements were made part of this ongoing Major Project. In 1991, after the Pantex Security Enhancements line item was designated a Major System Acquisition, the requirement was waived because portions of the Major System Acquisition had progressed beyond Key Decision 1, Approval of New Start. Noncompliance with the documentation requirements of the Department's Project Management System was previously reported by the Office of Inspector General (DOE/IG-0292, issued November 1990) and the General Accounting Office (GAO/RCED-92-2045FS, issued August 1992).

\section{PROJECTED SAVINGS}

Cancelling construction of the physical training facility project would save about $\$ 1.7$ million. Approximately $\$ 2.2$ million would be needed to complete the project. However, about $\$ 500,000$ is needed to make necessary repairs to the existing facilities, thus resulting in a net savings to the Department of about $\$ 1.7$ million. 


\section{Weapons Tactics and Training Facility}

\section{FINDING}

Effective planning for Major System Acquisitions requires that competitive alternatives be explored to ensure that a more costly or less effective option is not chosen. However, Mason \& Hanger did not fully analyze all viable alternatives to constructing a $\$ 5.7$ million weapons tactics and training facility. Had a Justification for New Start been prepared and reviewed in accordance with the Department's project management system, a different approach to meeting mission needs may have been chosen. Complete analyses of alternatives to the proposed facility could still result in substantial savings to the Department:

\section{RECOMMENDATION}

We recommend that the Manager, Albuquerque Operations Office, direct Mason \& Hanger to perform economic analyses of all viable alternatives to the proposed weapons tactics and training facility before proceeding with construction.

\section{MANAGEMENT REACTION}

Management concurred with the recommendation to conduct economic analyses of all viable alternatives. Part III of this report includes detailed management and auditor comments.

\section{DETAILS OF FINDING}

\section{EXISTING WEAPONS TACTICS AND TRAINING FACILITIES}

Weapons tactics and training at pantex is currently conducted on three firing ranges. Range 1, which opened in 1976, is the largest and is used for most firearms training at Pantex. The range, which is also used by the Department's Pantex Courier Section, can be used at night and includes an automated target system. This range will not be used upon completion of the proposed weapons tactics and training facility. Range 2 was built in the 1950 's and is used primarily for tactics training. This range, which is small in size, is also used for pistol and submachine gun training on a contingency basis. Range 3, which opened in about 1990, is used for big bore firing. According to a Pantex security instructor, this range can only be used 96 days a year per a lease agreement with Texas Tech University. Approximately 370 Pantex security officers and 130 Courier section personnel use the Pantex ranges. 
JUSTIFICATION AND DESCRIPTION OF PROPOSED FACILITY

According to the Department, the proposed weapons tactics and training facility is necessary to provide centralized arms training and qualification capabilities for the Pantex security force and Pantex Courier section. This facility will provide the capability for implementation of advanced Iive-fire training concepts, neutralization of hostile force tactics, stress/decision shooting, and night-fire training. The proposed facility. will consist of an M-16 rifle range, police pistol combat range, combined M-16/police pistol combat range, tactical firing range, shoothouse, and 14,300-square-foot building complete with an indoor firing range and two classrooms.

\section{DEPARTMENTAL REOUIREMENTS}

DOE Order 4700.1 was issued in March 1987 to provide a disciplined, systematic and coordinated approach to project management, resulting in efficient planning of DOE projects. The Order requires that the Department consider the widest range of acquisition alternatives to satisfy the mission need. This approach ensures against choosing a project that may be either more costly or less effective than other options.

\section{EXPLORATION OF ALTERNATIVES}

Mason \& Hanger considered and rejected two alternatives to constructing a weapons tactics and training facility. However, reasons for rejecting proposed alternatives were not fully supported. In 1988, Mason \& Hanger rejected an alternative to modify the existing facility on the grounds that it would be more cost-effective to construct a new facility. However, Mason \& Hanger could not provide any economic analysis to support this position. Another alternative, to continue using the existing firing range, was rejected on the grounds that the range could not accommodate growth in the protective force. However, the force has grown and is meeting the Department's shooting qualification requirements using the existing facility. Department's Pantex Courier Section is also meeting its qualification requirements. Mason \& Hanger's rejection also asserted that the existing range was scheduled for demolition in 1992, but gave no reason why it should be demolished.

Other viable alternatives were not considered. For example, there appeared to be no consideration for performing some modifications to the existing facility in conjunction with constructing a smaller, less costly 
facility. This could perhaps result in deletion or reduction of some of the ranges in the proposed facility. In addition, there appeared to be no consideration for using local, State, and Federal law enforcement agencies' training facilities to the extent possible.

JUSTIFICATION FOR NEW START MAY HAVE MADE A DIFFERENCE

If a Justification for New Start for the Security Enhancements Major System Acquisition had been prepared and reviewed, the Department may have chosen a different approach for meeting the mission need. However, as stated in Finding 1, Department officials waived this requirement. In a properly prepared justification, management would have been required to document analyses of the most appropriate alternatives and reasons why proceeding with the project was the best option. Without this justification, senior management could not be assured that all viable alternatives had been considered and that construction of the proposed facility was cost effective for meeting mission requirements.

\section{POTENTIAL SAVINGS}

Complete analyses of all viable alternatives could result in savings to the Department. Such analysis, for example, could result in cancellation or rescoping of the proposed facility. Given the project's $\$ 5.7$ million total project cost, these savings could be substantial. 


\section{PART III}

\section{MANAGEMENT AND AUDITOR COMMENTS}

An exit conference was held on March 3, 1995, at which time Albuquerque and Pantex representatives expressed concern that the OIG did not consider the cost of making needed repairs to existing facilities in light of cancelling the proposed facility. After considering management's concerns, we asked Albuquerque officials to consider various alternatives in lieu of constructing the proposed physical training facility. The only alternative that management examined was a comparison of their original proposal to a specially designed modular building. No consideration was given to repairing and upgrading the existing facilities. Thus we considered management's actions to be nonresponsive. Management's issued response to the findings and recommendations, and auditor comments follow.

\section{Physical Training Facility.}

Management Comments. Management did not agree to our original recommendation to cancel the proposed facility and stated that construction of the facility was warranted by the planned long-term life of the Pantex Plant and the Protective Force. A total of 1,646 hours are utilized for security training during a training year. An additional three days of General Education Training must also be provided to 525 personnel in the safeguards, security and Fire Protection Division. Current training needs are met by the extraordinary effort of the training staff to schedule various training classrooms which are not co-located. Equipment used in the training is transported from classroom to classroom as needed. The facilities are also used by Fire Protection personnel for some of their classroom training and physical fitness training, and for the distance learning applications.

Regardless of the condition of the facility, training must be conducted and conducted successfully. Security personnel must meet physical fitness standards. The new facility provides a long-term permanent structure, which does not impede training due to structural conditions.

Auditor Comments. According to testimony recently given by the Assistant Secretary for Defense Programs to the Senate Appropriations Committee, the Pantex work load is expected to remain stable for the next several years. However, tight budgets in the foreseeable future require 
that Defense Programs deliver a smaller, more cost effective weapons complex. The Department's Defense Programs Investment Strategy is assessing ways to configure the future weapons complex to provide for anticipated future needs while adjusting to decreased budget levels. However, final decisions have not been reached on how this would impact on the long-term future of the Pantex Plant.

The Pantex Security Force meets and exceeds all training requirements. Existing classrooms and conference rooms throughout the Pantex Plant are utilized for classroom training. In addition, two more classrooms for security training will be available upon completion of the proposed weapons tactics and training facility.

While the number of people using the physical training facility may have increased over time, the protective force has maintained a very high physical fitness qualification rate, as evidenced by the 100 percent rate for the first six months of Fiscal Year 1994. Such a high qualification rate indicates that the existing facility meets mission needs. Also the requirements for physical training may be reduced, as shown on page 9 .

Management comments. The project was beyond Key Decision 0 , and a Justification for New start was not needed. Subsequent to DOE approval, the issue of not having a Justification for New Start was addressed and concurred with by the Energy System Acquisition Advisory Board.

Auditor comments. The project was designated a major system acquisition in March 1991. At that time, Department Order 4700 .I required that a Justification for New Start be prepared and approved for all major system acquisitions and major projects. Waiving this requirement for projects beyond Key Decision 0 was not effective until June 1992, more than one year later. Pantex officials could not provide us with any documentation to show that the Energy System Acquisition Board concurred with not having a Justification for New start.

2. Weapons Tactics and Training Facility.

Management Comments. Management agreed to perform economic analyses of all viable alternatives to constructing the proposed weapons tactics and training facility.

Management stated that construction of a shoothouse could be eliminated and that the security Force was in the process of procuring a modular shoothouse. Funds for constructing the shoothouse would be held as contingency for other projects in the Major System Acquisition. 
Modifying Range 1 in lieu of constructing any of the ranges designated for the Weapons Tactics and Training Facility was analyzed. However, the only range designated for the proposed facility that could possibly be replaced by Range 1 is the Transportation Safeguards Division Practical Pistol Course range. Costs to modify the existing range were estimated at $\$ 432,957$ versus the $\$ 397,422$ estimated to construct the proposed Practical Pistol Course range.

Possible expansion/modification of the Long Bore range and use of the Potter County shoothouse was also considered. However, it was determined that these options were not viable or too costly.

Auditor Comment. Management's comments are responsive to the recommendation. 
IG Report No. WR-B-95-06

\section{CUSTOMER RESPONSE FORM}

The Office of Inspector General has a continuing interest in improving the usefulness of its products. We wish to make our reports as responsive as possible to our customers' requirements, and therefore ask that you consider sharing your thoughts with us. On the back of this form, you may suggest improvements to enhance the effectiveness of future reports. Please include answers to the following questions if they are applicable to you:

1. What additional background information about the selection, scheduling, scope, or procedures of the audit or inspection would have been helpful to the reader in understanding this report?

2. What additional information related to findings and recommendations could have been included in this report to assist management in implementing corrective actions?

3. What format, stylistic, or organizational changes might have made this report's overall message more clear to the reader?

4. What additional actions could the office of Inspector General have taken on the issues discussed in this report which would have been helpful?

Please include your name and telephone number so that we may contact you should we have any questions about your comments.

Name

Date

Telephone

Organization

When you have completed this form, you may telefax it to the Office of Inspector General at (202) 586-0948, or you may mail it to:

Office of Inspector General (IG-1)

Department of Energy

Washington, D.C. 20585

ATTN: Customer Relations

If you wish to discuss this report or your comments with a staff member of the Office of Inspector General, please contact Wilma Slaughter at (202) 586-1924. 